\title{
Article
}

\section{Studies on Serum Creatinine and Creatinine Clearance in Hypertensive Patients}

\author{
Sarkar D ${ }^{1}$, Latif SA ${ }^{2}$, Aich $\mathrm{J}^{3}$, Uddin MM ${ }^{4}$
}

Objectives: To assess the serum creatinine and creatinine clearance values in hypertensive patients for providing information to the health-policy planners, clinical practitioners about the importance of routine monitoring of serum creatinine and creatinine clearance in hypertensive patients for prevention of ESRD and other consequences to combat morbidity and mortality and to reinforce the need to consider these parameters in daily clinical practice. Study design: It was a cross-sectional study. Setting: The study was conducted at Department of Physiology and Biochemistry of Mymensingh Medical College, Medicine Unit of Mymensingh Medical College Hospital. Study period: The period of the study was January 2005 to December 2005. Participants: A total number of seventy subjects were included in this study. Out of 70 subjects, 40 (forty) were hypertensive patients and 30 (thirty) were normotensive \& healthy controls. Intervention: The subjects were selected on the basis of history and clinical examination. Convenient sampling technique was applied. During visit the available hypertensive patients and controls (normotensive \& healthy) those who were present were selected. Having received their written consent they were interviewed \& examined by prepared personal data sheet and sample of blood (after overnight fasting) was drawn for biochemical examination. Main outcome measure: Mean values of serum creatinine and creatinine clearance. Result: Serum creatinine was greater in hypertensive than those of normotensive. Creatinine clearance was less in hypertensive than those of normotensive. Serum creatinine \& creatinine clearance in between males hypertensive $\&$ control shows that $\mathrm{CrCl}$ were statistically significant but not the serum creatinine. In females of hypertensive \& control shows no differences in case of SCr \& $\mathrm{CrCl}$. Among 40 hypertensive the number of "Getting treatment - regular" \& " Getting treatment-irregular" was $14(35 \%)$ \& 26 (65\%) respectively. Similarly in patients "suffering less than $5 \mathrm{yrs"}$ " and "suffering $5 \mathrm{yrs} \&$ above" the differences are also not statistically significant. Conclusion: The observations of this study revealed that most of the hypertensive patients were taking treatment irregularly and there was significant alteration of biochemical parameters in hypertensive patients. Therefore, for routine monitoring of hypertensive patients to prevent the end stage renal disease (ESRD) and other consequences, the reinforcement of the investigations of these parameters may be recommended in daily clinical practice.

Key Words: Hypertension, creatinine, creatinine clearance, Cockcroft-Gault formula

\section{Introduction}

A mong all cardiovascular diseases hypertension is the commonest in all over the world including Bangladesh. ${ }^{1}$ The prevalence pattern of hypertension in developing countries is different from that in the developed countries. Adults (18 years and above) in Bangladesh suffers from hypertension. In different studies it has been shown that $70 \%$ of strokes, $23.8 \%$ of myocardial infarction and heart failures, and $11 \%$ of renal failures are attributed due to hypertension in Bangladesh. ${ }^{2}$ 


\section{Article}

Hypertension and renal function are closely related. The majorities of the hypertensive patients are asymptomatic and left untreated, so complication develops and become fatal. It may lead to heart failure and to renal damage ${ }^{3}$. Chronic kidney failure usually develops slowly with few signs or symptoms in the early stages. It may occur in association with hypertension. Many people with chronic kidney failure don't realize they have a problem until their kidney function has decreased to less than 25 percent of normal. As the disease can readily be detectable and treatable, so early diagnosis and treatment can greatly reduce morbidity and mortality.

Systolic hypertension has been considered to be one of the most important causes of morbidity and mortality leading to cerebrovascular stroke, cardiovascular and renal diseases 4,5 .

In hypertension the basic or minimal evaluation recommended for patients includes history and physical examination, $\mathrm{CBC}$, urinalysis, serum analysis for creatinine; serum total cholesterol, high density, and low density lipoprotein cholesterol and $\mathrm{ECG}^{6}$.

Creatinine (a breakdown product of creatine which is an important component of muscle) is excreted exclusively by the kidneys, and its level in the blood is proportional to the glomerular filtration rate. The serum creatinine level provides a more sensitive test of kidney function than BUN because kidney impairment is almost the only cause of elevated creatinine.

Creatinine clearance rate determines how efficiently the kidneys are clearing creatinine from the blood and serves as an estimate of kidney function. A low creatinine clearance value indicates abnormal kidney function. Routine evaluation of creatinine clearance could be useful for identifying patients at higher cardiovascular risk.

Early diagnosis of mild chronic renal insufficiency (MCRI) through the determination of serum creatinine and creatinine clearance is most important for combating morbidity and mortality in hypertension.

The number of patients developing end stage renal disease (ESRD) as a consequence of hypertension is increasing and accounts for $25 \%$ of new cases of ESRD in the United States. It is also proposed that mild to moderate hypertension can lead to ESRD ${ }^{7}$.

Estimation of Serum creatinine and creatinine clearance are used as markers of renal function, which may give prior intimation for alerting hypertensive patient of developing ESRD.

Indices of altered renal function are independent predictors of $\mathrm{CV}$ morbidity and mortality. ${ }^{8}$ Recent analyses of the influence of renal function on the cardiovascular outcome in trials performed inpatients with essential hypertension $9,10,11$ have confirmed the relevance of the kidney in cardiovascular prognosis since the initial stages of renal failure. The diagnosis of a deranged renal function in clinical practice is based mainly on the finding of changes in serum creatinine, and/ or the detection of an elevated urinary excretion of albumin below (microalbuminuria) or above (macroalbuminuria), the usual laboratory methods to detect proteinuria. An increase in serum creatinine above normal values or the presence of proteinuria or microalbuminuria could constitute the most potent predictors for the future development of cardiovascular death in essential hypertension. The clinical relevance of these findings is reinforced by its simplicity in clinical practice. Evaluation of glomerular filtration rate through estimation of creatinine clearance ${ }^{12}$ or its determination after 24-hour urine collection is not usually performed in clinical practice. However, it has been shown to be a useful predictor of cardiovascular risk when values are below 60-70 $\mathrm{ml} / \mathrm{min} 9,11$.

Creatinine clearance can be estimated by Cockcroft-Gault formula. The index proposed by Cockcroft and Gault is highly reliable and widely used. The Cockcroft-Gault equation aims

J Bangladesh Soc Physiol. 2006 Dec;(1):19-26 


\section{Article}

to predict creatinine clearance from knowledge of serum creatinine, age and weight. ${ }^{13}$ Increase of serum creatinine and decrease of creatinine clearance are the early sign of renal impairment like MCRI. Through the determination of serum creatinine and creatinine clearance in patients with hypertension, renal impairment can be diagnosed early; so that by proper management in time, morbidity and mortality of hypertensive patients can be prevented.

So this study is designed to explore the relation or changes in the parameters e.g. serum creatinine, creatinine clearance in hypertension in our setting and the findings of this study will provide information to the health-policy planners and also the clinical practitioners about the importance of routine monitoring of serum creatinine, creatinine clearance in hypertensive patients through which they can prevent end stage renal disease (ESRD) and other consequences and thus can combat morbidity and mortality and to reinforce further the needs for investigation of these parameters in hypertensive patients during the daily clinical practice. Therefore, this study has a great value in this regard. The objectives of this study are (1) To assess the trend of level of serum creatinine and creatinine clearance in hypertensive patient for monitoring renal function and to reinforce further the need of routine investigation of these parameters in daily clinical practice for better management of hypertensive patients. (2) To utilize these results as background information both for preventive and therapeutic measure to minimize the risk of complication of hypertension in our socioeconomic context. (3) To compare the results of this study with those conducted in other setting by other countries, so that it dictates us to think globally and to act locally.

\section{Methods}

A cross-sectional study was conducted during the period of January 2005 to December 2005 at Department of Physiology and Biochemistry of Mymensingh Medical College, Medicine Unit of Mymensingh Medical College Hospital and in the community of Sadar, Mymensingh District.
In this study 70 (seventy) subjects of both sexes participated. (a) Group-I (study group) included 40 (forty) patients of hypertension. If an individual had a history of hypertension and / or was using antihypertensive agents or if the systolic blood pressure (SBP) exceeded 140 $\mathrm{mmHg}$ or the diastolic blood pressure (DBP) exceeded $90 \mathrm{mmHg}$ was considered as hypertensive ${ }^{14}$. (b) Group-II (Control group) included 30(thirty) normotensive and healthy individual. The persons whose blood pressure was within normal limit $(\mathrm{BP}<140 / 90 \mathrm{mmHg})$ and who had no history of previous hypertension.

From the study group the patients with secondary hypertension and from both the study and control group patients with history of diabetes mellitus, overt vascular disease (angina, previous myocardial infarction, transient ischemic attack, stroke, intermittent claudicating, amputation for vascular disease), renal or hepatic impairment $\&$ those who are on lipid-lowering drugs or hormone replacement therapy were excluded.

On the basis of history and clinical examination the subjects were selected. No sampling technique was applied. During visit the available hypertensive patients and controls (normotensive and healthy) those who were present were interviewed, examined and sample of blood was drawn. A research instrument (Personal data sheet) was developed for this study and that contains Part-A: general information (name, age, sex, address, educational status, occupation, monthly income and physical activity), Part-B: personal information consisting of history taking $\&$ general examination and Part-C: parameters i.e. result of biochemical tests.

On the day of visit the purpose of the study was explained to the available patient of hypertension and/or control (i.e. normotensive \& healthy) and an instantaneous written informed consent was taken before interview. The interview and clinical examination for each took about 45 minutes.

In history of hypertension, period of suffering is defined as "the length of period starting from first diagnosis of hypertension to till date". And 


\section{Article}

"Getting treatment-regular" is defined as the patient suffering from hypertension is regularly checked by a Physician \& takes antihypertensive agents according to the direction of the Physician. Similarly "Getting treatment-irregular" is defined as the patient suffering from hypertension is not regularly checked by a Physician \& does not take antihypertensive agents according to the direction of the Physician. He is self-medicated according to his body need.

The blood pressure of the individual was measured (after complete rest \& patient/ control should not smoke or drink caffeinated beverages within 30 minutes of the measurement) by an aneroid sphygmomanometer and an appropriate sized cuff encircling at least $80 \%$ of the arm in the seated posture, with feet on the floor and arm supported at heart level ${ }^{15}$. Two measurements about 5-10 minutes apart were taken. Then the averages of the two measurements were recorded. Systolic BP is the point at which the first of 2 or more sounds is heard (phase 1) and diastolic BP is the point before the disappearance of sounds (phase 5).

The subjects were requested for collection of blood at morning on the next day after overnight fasting (i.e. fasting for 10 - 12 hours). About 5 $\mathrm{ml}$ of venous blood was collected directly from anti-cubital vein by disposal syringe from each individual (both study population \& control) under strict aseptic precaution and kept using no anticoagulant at room temperature. When the clot had formed the test tubes were centrifuged at 2000 to $3000 \mathrm{rpm}$ for 10 minutes. The serum obtained by centrifuging was collected in another test tube labeled with name, date \& time of collection. Biochemical analysis was carried out immediately after sampling but in case of any delay the serum samples were stored in a refrigerator at $4^{\circ} \mathrm{C}$ up to 24 hours.

Biochemical analysis of serum was carried out for estimation of (1) Serum creatinine with alkaline picrate method. (2) Creatinine clearance was estimated by Cockcroft- Gault Formula.
Cockcroft-Gault Formula for Estimating Creatinine Clearance $(\mathrm{CrCl}){ }^{16}$. Estimated $\mathrm{CrCl}=$

$$
\begin{aligned}
& \frac{(140-\text { Age in years }) \times \text { Body weight in } \mathrm{Kg}}{\text { Serum creatinine }(\mathrm{mg} / \mathrm{dl}) \times 72} \\
& \text { Multiply the result by } 0.85 \text { for women } \text {. }
\end{aligned}
$$

Important variables were considered and collected data were analyzed to fulfill the objectives set for the study. The results were calculated and analyzed by SPSS program. To find the statistical significance unpaired " $t$ test" was done when appropriate.

\section{Results}

In Group - I (hypertensive) 40 patients of hypertension and in Group-II (normotensive) 30 normal persons were included in this study. In Group-I male and female participation was 17 (42.5\%) and 23 (57.5\%) and in Group-II male and female was $15(50 \%)$ and $15(50 \%)$ respectively.

The age range and average age in Group-I and Group-II was (42-70 years, $54.60 \pm 7.71$ years) and (32-70 yrs, $52.23 \pm 11.63 \mathrm{yrs})$. The two groups did not differ in respect of age, sex and occupation.

Table-I shows that the level of serum creatinine (mean \pm SE) in Group-I (hypertensive) was higher than that of Group-II (normotensive) i.e. 0.86

Table I: Shows comparative analysis of serum creatinine \& creatinine clearance in hypertensive (study) and in control group

\begin{tabular}{llll}
\hline Parameter & Group & Mean \pm SE & P value \\
\hline & $\begin{array}{c}\text { Study } \\
\mathrm{n}=40\end{array}$ & $0.86 \pm 3.20$ & \\
$\mathrm{SCr}(\mathrm{mg} / \mathrm{dl})$ & & \multicolumn{2}{c}{$0.990461 \mathrm{NS}$} \\
& $\begin{array}{c}\text { Control } \\
\mathrm{n}=30\end{array}$ & $0.79 \pm 4.01$ & \\
& $\begin{array}{c}\text { Study } \\
\mathrm{n}=40\end{array}$ & $73.37 \pm 2.97$ & \\
& & & $0.005466^{*}$ \\
$\mathrm{CrCl}(\mathrm{ml} / \mathrm{min}$ & $\mathrm{C}$ & $89.93 \pm 4.96$ & \\
& $\mathrm{n}=30$ & & \\
\hline
\end{tabular}

$\mathrm{SCr}=$ Serum creatinine, $\mathrm{CrCl}=$ Creatinine clearance, $\mathrm{N}$ $=$ Total number of subjects in each group, ${ }^{*}=$ Statistically significant, NS $=$ Not statistically significant

J Bangladesh Soc Physiol. 2006 Dec;(1):19-26 


\section{Article}

Table II: Comparative analysis of serum creatinine \& creatinine clearance in males \& females between Group -I (Hypertensive) and Group - II (Control)

\begin{tabular}{|c|c|c|c|}
\hline Parameter & Group & Mean \pm SE & $\mathrm{p}$ value \\
\hline \multirow{5}{*}{$\mathrm{SCr}(\mathrm{mg} / \mathrm{dl})$} & $\begin{array}{l}\text { Male (Gr-I) } \\
\mathrm{n}=17\end{array}$ & $0.95 \pm 0.05$ & \multirow[b]{2}{*}{$0.396610^{\mathrm{NS}}$} \\
\hline & $\begin{array}{l}\text { Male (Gr-II) } \\
\mathrm{n}=15\end{array}$ & $0.89 \pm 0.05$ & \\
\hline & & & \\
\hline & $\begin{array}{l}\text { Female }(\mathrm{Gr}-\mathrm{I}) \\
\mathrm{n}=23\end{array}$ & $0.78 \pm 0.04$ & \multirow[b]{2}{*}{$0.142334^{\mathrm{NS}}$} \\
\hline & $\begin{array}{l}\text { Female (Gr-II) } \\
\mathrm{n}=15\end{array}$ & $0.69 \pm 0.05$ & \\
\hline \multirow{5}{*}{$\mathrm{CrCl}(\mathrm{ml} / \mathrm{min})$} & $\begin{array}{l}\text { Male (Gr-I) } \\
\mathrm{n}=17\end{array}$ & $77.84 \pm 0.86$ & \multirow[b]{2}{*}{$0.035648 *$} \\
\hline & $\begin{array}{l}\text { Male (Gr-II) } \\
\mathrm{n}=15\end{array}$ & $97.91 \pm 2.20$ & \\
\hline & & & \\
\hline & $\begin{array}{l}\text { Female(Gr-I) } \\
\mathrm{n}=23\end{array}$ & $70.07 \pm 3.38$ & \multirow[b]{2}{*}{$0.095873^{\mathrm{NS}}$} \\
\hline & $\begin{array}{l}\text { Female (Gr-II) } \\
\mathrm{n}=15\end{array}$ & $81.96 \pm 6.09$ & \\
\hline
\end{tabular}

$\mathrm{Scr}=$ serum creatinine, $\mathrm{CrCl}=$ creatinine clearance, $\mathrm{n}=$ total number of subjects in each group, $*=$ significant, NS $=$ not significant

$\pm 3.20 \mathrm{mg} / \mathrm{dl}$ vs. $0.79 \pm 4.01 \mathrm{mg} / \mathrm{dl}$, p value $=$ 0.990461 ; and creatinine clearance was lower i.e. $73.37 \pm 2.97 \mathrm{ml} / \mathrm{min}$ vs. $89.93 \pm 4.96 \mathrm{ml} / \mathrm{min}$, $\mathrm{p}$ value $=0.005466$ respectively. The difference of serum creatinine between two groups was statistically insignificant but in case of creatinine clearance it was significant.

Table-II, shows serum creatinine is higher $(0.98 \pm 0.05 \mathrm{mg} / \mathrm{dl}$ vs. $0.89 \pm 0.05 \mathrm{mg} / \mathrm{dl}, \mathrm{p}$ value $=$ $0.396610)$ and creatinine clearance is lower $(77.84 \pm 5.20 \mathrm{ml} / \mathrm{min}$ vs. $97.91 \pm 7.48 \mathrm{ml} / \mathrm{min}, \mathrm{p}$ value $=0.035684$ ) in male Group-I (hypertensive) than those of male Group-II (control).

In case of creatinine clearance the difference is statistically significant but in case of serum creatinine it is statistically insignificant. Serum creatinine is higher $(0.78 \pm 0.04 \mathrm{mg} / \mathrm{dl}$ vs $0.69 \pm 0.05 \mathrm{mg} / \mathrm{dl}, \mathrm{p}$ value $=0.142334)$ and

J Bangladesh Soc Physiol. 2006 Dec;(1):19-26 creatinine clearance is lower $(70.07 \pm 3.38 \mathrm{ml} / \mathrm{min}$ vs. $81.96 \pm 6.09 \mathrm{ml} / \mathrm{min}, \mathrm{p}$ value $=0.095873)$ in female Group-I (hypertensive) than those of female Group-II (control). The differences are not statistically significant.

According to getting their treatment Group-I (hypertensive) was divided in two groups - a) Treatment getting regularly and b) Treatment getting irregularly.

A comparison was done according to the characteristic of getting treatment. Among 40 hypertensive patients, the number of getting treatment regular and treatment irregular was 14 (35\%) and $26(65 \%)$ respectively.

In Table-III, a comparison between those two groups in case of serum creatinine and creatinine clearance shows that in "Treatment regular"

Serum creatinine was lower $(0.81 \pm 0.05 \mathrm{mg} / \mathrm{dl}$ vs. $0.87 \pm 0.04 \mathrm{mg} / \mathrm{dl}, \mathrm{p}$ value $=0.142334)$ and Creatinine clearance was higher $(79.73 \pm 5.30 \mathrm{ml} /$ $\min$ vs. $69.95 \pm 3.51 \mathrm{ml} / \mathrm{min}$, $\mathrm{p}$ value $=0.095873$ ) than those of "Treatment irregular group". The differences were statistically insignificant.

According to the period of suffering a comparison was done by dividing the Group-I (hypertensive) into 2 groups, i.e. 1) suffering from hypertension less than 5 years and 2) suffering from hypertension for 5 years and above. Period of suffering from hypertension less than 5 years was $17(42.5 \%)$ and period 5 years and above was $23(57.5 \%)$.

In Table-III, comparison between those two groups in case of serum creatinine and creatinine clearance shows that in "Group suffering less than 5 years" serum creatinine was lower $(0.83 \pm 0.05$ $\mathrm{mg} / \mathrm{dl}$ vs. $0.86 \pm 0.04 \mathrm{mg} / \mathrm{dl}, \mathrm{p}$ value $=0.873729)$ and creatinine clearance was higher $(77.06 \pm 5.54$ $\mathrm{ml} / \mathrm{min}$ vs. $70.36 \pm 3.51 \mathrm{ml} / \mathrm{min}, \mathrm{p}$ value $=$ 0.395182 ) than those of "Group suffering 5 years and above". The differences were not statistically significant. 


\section{Article}

Table -III. Comparative analysis of serum creatinine \& creatinine clearance between "Suffering less than 5 years" and "Suffering 5 years and above" and "Getting treatment regular" and "Getting treatment irregular" by SPSS.

\begin{tabular}{llcc}
\hline Parameter & Group & Mean \pm SE & p value \\
\hline & $\mathrm{S}(\mathrm{L}) \mathrm{n}=17$ & $0.83 \pm 0.05$ & \\
& $\mathrm{~S}(\mathrm{M}) \mathrm{n}=23$ & $0.86 \pm 0.04$ & $0.873729^{\mathrm{NS}}$ \\
$\mathrm{SCr}(\mathrm{mg} / \mathrm{dl})$ & $\mathrm{T}(\mathrm{R}) \mathrm{n}=14$ & $0.81 \pm 0.05$ & \\
& $\mathrm{~T}(\mathrm{I}) \mathrm{n}=26$ & $0.87 \pm 0.04$ & \\
& $\mathrm{~S}(\mathrm{~L}) \mathrm{n}=17$ & $77.06 \pm 5.54$ & \\
& $\mathrm{~S}(\mathrm{M}) \mathrm{n}=23$ & $70.36 \pm 3.51$ & \\
$\mathrm{CrCl}(\mathrm{ml} / \mathrm{min})$ & $\mathrm{T}(\mathrm{R}) \mathrm{n}=14$ & $79.73 \pm 5.30$ & \\
& & & $0.09584^{\mathrm{NS}}$ \\
& $\mathrm{T}(\mathrm{I}) \mathrm{n}=26$ & $69.95 \pm 3.51$ & \\
\hline
\end{tabular}

$\mathrm{SCr}=$ Serum creatinine, $\mathrm{CrCl}=$ Creatinine clearance,

$\mathrm{N}=$ Total number of subjects in each group, $\mathrm{NS}=$ Not statistically significant, $\mathrm{S}(\mathrm{L})$ = Suffering less than 5 years, $\mathrm{S}(\mathrm{M})$ = Suffering for 5 years and above, $\mathrm{T}(\mathrm{R})=$ Getting treatment regular, $\mathrm{T}(\mathrm{I}) \quad=$ Getting treatment irregular

\section{Discussion}

Many studies on serum creatinine and creatinine clearance have been done in relation to the risk of renal diseases such as ESRD, renal failure, etc. But there are a few studies in relation to hypertension have been found.

The observations in this study are discussed herewith. Similar observations were made by other researchers also, which are discussed below.

In this study serum creatinine was higher in hypertensive than control (normotensive) i.e. $0.86 \pm 3.20 \mathrm{mg} / \mathrm{dl}$ Vs $0.79 \pm 4.01 \mathrm{mg} / \mathrm{dl}, \mathrm{p}=$ 0.990461 . Creatinine clearance was lower in Group-I (Hypertensive) than those of Group-II (normotensive \& healthy) i.e. $73.37 \pm 2.97 \mathrm{ml} / \mathrm{min}$ Vs $89.93 \pm 4.96 \mathrm{ml} / \mathrm{min}, \mathrm{p}=0.005466$. The difference was statistically significant in case of creatinine clearance but in case of serum creatinine it was not statistically significant.
Similar result was found in the Third National Health \& Nutrition Examination Survey (NHANES III) ${ }^{17}$ in which serum creatinine was higher in presence of hypertension and it was strongly related to inadequate treatment of high blood pressure.

Similarly the study of Kadiri ${ }^{18}$ showed that the serum creatinine was higher in hypertensive than in normotensive but the differences were not statistically significant. Adjusted creatinine clearance was significantly lower in hypertensive than normotensive (both in male and female).

In British Regional Heart Study 19 it was observed that elevated serum creatinine was present in $8.6 \%$ of normotensive and in $13.8 \%$ of hypertensive (test for difference, $\mathrm{p}<0.001$ ). In this study serum creatinine was higher in male group-I (hypertensive) than those of male groupII (Control \& normotensive) i.e. $0.95 \pm 0.05 \mathrm{mg}$ / dl Vs $0.89 \pm 0.05 \mathrm{mg} / \mathrm{dl}(\mathrm{p}=0.396610)$. But in case of creatinine clearance it was lower than that of male group-II that is $77.84 \pm 5.20 \mathrm{ml} / \mathrm{min}$ Vs $97.91 \pm 7.48 \mathrm{ml} / \mathrm{min}(\mathrm{p}=0.035648)$. Except serum creatinine the difference in creatinine clearance between two groups is statistically significant.

Similarly the study of Kadiri ${ }^{18}$ showed that adjusted serum creatinine clearance was significantly lower in hypertensive males than normotensive males $(86 \pm 20 \mathrm{ml} / \mathrm{min} \mathrm{Vs} 99 \pm 21 \mathrm{ml} /$ $\min , \mathrm{p}<0.01)$.

In this study serum creatinine was higher in Female group-I (hypertensive) than those of Female group-II (Control \& normotensive) i.e. $0.78 \pm 0.04 \mathrm{mg} / \mathrm{dl}$ Vs $0.69 \pm 0.05 \mathrm{mg} / \mathrm{dl}$ ( $\mathrm{p}=$ 0.142334 ). But in case of creatinine clearance it was lower than that of Female group-II that is $70.07 \pm 3.38 \mathrm{ml} / \mathrm{min} \mathrm{Vs} 81.96 \pm 6.09 \mathrm{ml} / \mathrm{min}(\mathrm{p}=$ 0.095873 ) . In case of serum creatinine and creatinine clearance the difference between two groups are statistically not significant.

Similarly the study of Kadiri ${ }^{18}$ showed that adjusted serum creatinine clearance was

J Bangladesh Soc Physiol. 2006 Dec;(1):19-26 


\section{Article}

significantly lower in hypertensive than normotensive in females $(84 \pm 19 \mathrm{ml} / \mathrm{min}$ Vs 96 $\pm 19 \mathrm{ml} / \mathrm{min}, \mathrm{p}<0.01)$.

In case of "Irregularly treated hypertensive patient" serum creatinine was higher than "Regularly treated hypertensive patient" i.e. $0.87 \pm 0.04 \mathrm{mg} / \mathrm{dl} \mathrm{Vs} 0.81 \pm 0.05 \mathrm{mg} / \mathrm{dl}, \mathrm{p}=$ 0.142334 but in case of creatinine clearance it was lower than "Regularly treated hypertensive patient" i.e. $69.95 \pm 3.51 \mathrm{ml} / \mathrm{min}$ Vs $79.73 \pm 5.30$ $\mathrm{ml} / \mathrm{min}, \mathrm{p}=0.095873$.

In the result of Third National Health \& Nutrition Examination Survey (NHANES III) ${ }^{17}$ elevated serum creatinine level, an indicator of chronic renal disease was common and strongly related to inadequate treatment of high blood pressure.

In this study, creatinine clearance were higher in hypertensive "suffering less than 5 years" than those of "suffering 5years and above" i.e. 77.06 $\pm 5.54 \mathrm{ml} / \mathrm{min}$ Vs $70.36 \pm 3.51 \mathrm{ml} / \mathrm{min}(\mathrm{p}=$ 0.395182 ). But in case of serum creatinine it was lower than that of "suffering $5 \mathrm{yrs}$ and above" i.e. $0.83 \pm 0.05 \mathrm{mg} / \mathrm{dl} \mathrm{Vs} 0.86 \pm 0.04 \mathrm{mg} / \mathrm{dl}(\mathrm{p}=$ 0.873729 ). The differences in all the parameters between two groups were not statistically significant.

A study by Leoncini ${ }^{20}$ on never previously treated, middle aged patients with primary hypertension showed that creatinine clearance was inversely related to the duration of disease ( $\mathrm{r}=-0.132, \mathrm{p}<0.0001)$.

In the Multiple Risk Factor Intervention Trial ${ }^{21}$, no relationship was seen between blood pressure at base line and serum creatinine levels, but those with higher blood pressures showed the greatest increase in serum creatinine over 6 years follow up.

In a research conducted by Rosansky ${ }^{22}$ on 897 subjects followed up for 9 years. In that, subjects with essential hypertension had a considerably superior rate of turn down in renal function compared with normotensive subjects. These observations suggest that blood pressure elevation below the usual levels at which definite hypertension is diagnosed may induce early renal damage.

Ji-Gaung Wang ${ }^{23}$ observed that in hypertensive serum creatinine was higher in men than women $(115 \pm 48 \mu \mathrm{mol} / \mathrm{L}$ Vs $94.39 .3 \mu \mathrm{mol} / \mathrm{L}$ respectively, $\mathrm{p}<0.001)$. In my study the serum creatinine was also higher in men than in women $(0.98 \pm 0.05$ $\mathrm{mg} / \mathrm{dl}$ Vs $0.78 \pm 0.04 \mathrm{mg} / \mathrm{dl}$ ).

Conclusion:

Most of the hypertensive patients $(65 \%)$ are taking treatment irregularly. The hypertensive is prone to develop elevated level of serum creatinine and decreased level of creatinine clearance than those of normotensive healthy persons.

For routine monitoring of hypertensive patients to prevent the end stage renal disease (ESRD) and other consequences it is needed to reinforce the investigations of these parameters in daily clinical practice.

Small size of the sample was an important limitation of the present study. As various biochemical (serum creatinine and creatinine clearance) alterations found herewith, so a large scale Cross sectional study may be planned for more assurance.

\section{Author Affiliations}

*1. Dr Debjani Sarkar, Lecturer of Physiology, Mymensingh Medical College, Mymensingh, Bangladesh, Email: mmcphysiology@yahoo.com

2. Professor Shah Abdul Latif, Professor and Head of Physiology, Mymensingh Medical College, Mymensingh, Bangladesh. E-mail: salatif@bttb.net.bd

3. Dr Jyotirmay Aich, Deputy Civil Surgeon, Netrokona, Bangladesh

4. Dr M Murshed Uddin, Associate Professor of Physiology, Mymensingh Medical College, Mymensingh, Bangladesh

* for correspondence 


\section{Article}

\section{References}

1. Rashid KM, Khabiruddin M, Hyder S, editors. Textbook of Community Medicine and Public health. 1 ${ }^{\text {st }}$ dition. Dhaka: RKH Publishers; 1992.

2. Khandaker RK, Khandaker N. Control of Obesity and Hypertension in Bangladesh. Available from: http:/ /www.bhli.org.cn/ hylio/2003/ lwlxb-eng.htm

3. Smithon J: Hypertension. 11 March 2005. Available from: http://www.gp-training/clinical/hypert.htm.

4. National high blood pressure education program working group. National high blood pressure education program working group report in the elderly. Hypertension.1994; 23:275-85.

5. SHEP Cooperative Research Group. Prevention of stroke by antihypertensive drug treatment in older persons with isolated systolic hypertension. JAMA.1991; 265:3255-64.

6. Gifford RW Hypertension. In: Berkow R, editor. The Merk Manual. USA: Merk \& Co; 1982. p.391.

7. Weisstuch JM, Dworkin D. Does essential hypertension cause end-stage renal disease? Kidney.1992 ; 36 Suppl I: S 33-7. PMID: 1614065 (Pub Med- indexed for MEDLINE).

8. Segura J, Campo C, Ruilope LM. Chronic kidney disease and global cardiovascular risk in essential hypertension. Minerva Med. 2004;95(5): 375-83.

9. Ruilope LM, Salvetti A, Jamerson K, Hansson L, Warnold I, Wedel H, et al. Renal function and intensive lowering of blood pressure in the hypertensive subjects of the Hypertension Optimal Treatment (HOT) Study. J Am Soc Nephrol 2001; 12:218-25.

10. Brown MJ, Palmer CR, Castaigne A, de Leeuw P, Mancia G, Ruilope LM. Morbidity and mortality in patients randomized to double-blind treatment with long-acting calcium-channel blocker or diuretic in the International Nifedipine GITS study: Intervention as a Goal in Hypertension Treatment (INSIGHT). Lancet 2000;356:366-72.

11. Mann JFE, Gerstein HC, Pogue J, Bosch J, Yusuf S on behalf of the HOPE investigators. Renal insufficiency as predictor of cardiovascular outcomes and impact of ramipril: The HOPE randomization trial. Ann Intern Med 2001; 134(8):629-36.

12. Cockroft DW, Gault MH. Prediction of creatinine clearance from serum creatinine. Nephron 1976; $16: 31-41$.
13. Turner N. GFR estimation. [ Updated Tuesday, April 12, 2005.] Available from: http://renux.dmed.ed.ac.uk/ EdREN / Handbookbits /HDBKgfrest.html

14. Corti MC, Guralink JM, Salive ME, Harris T, Ferrucci L, Robert J, et al. Clarifying the Direct Relation between Total Cholesterol Levels and Death from Coronary Heart Disease in Older Persons. Ann Intern Med. 1997; 126(10): 753-60.

15. Das SK, Sanyal K, Basu A. Study of urban community survey in India: growing trend of high prevalence of hypertension in a developing country. Int J Med Sci. 2005; 2(2): 70-78. Published online 2005 April 1.

16. Clinical calculators: Creatinine clearance Calculator. Created by Moore C, McGinn T and Warren Ho. EBM website. Available from :www.mssm.edu/ medicine/general-medicine/ebm/CPR/TOOLS/ CrClearance.html

17. Coresh J, Wei GL; McQuillan G, Brancati FL, Levey AS, Jones C, et al. Prevalence of High Blood Pressure and Elevated Serum Creatinine Level in the United States. Findings from the Third National Health and Nutrition Examination Survey (1988- 1994). Arch Intern Med. 2001; 161:1207-16.

18. Kadiri S, Ajayi SO. Variability in the relationship between serum creatinine and creatinine clearance in hypertensive and normotensives with normal renal function. Afr J Med Med Sci. 2000 ; 29(2): 93-6.

19. Wannamethee SG, Shaper AG, Perry IJ. Serum Creatinine Concentration and Risk of Cardiovascular Disease. Stroke.1997;28:557-63.

20. Leoncini G, Viazzif F, Parodi D, Ratto E, Vettoretti S, Vaccaro V, et al. Creatinine clearance \& Signs of end organ damage in primary hypertension. Department of Internal Medicine, University of Genoa, enoa, Italy. J Hum Hypertens. 2004 ; 18(7): 511-6.

21. Alker G, Neaton J, Cutler JA, Neuwirth R, Cohen JD. Renal function change in hypertensive members of the Multiple Risk Factor Intervention Trial: racial and treatment effects. JAMA. 1992; 268:3085-91.

22. Rosansky SJ, Hoover DR, Kig L, Gibson J. The association of blood pressure levels and change in renal function in hypertensive and non-hypertensive subjects. Arch Intern Med. 1990; 150:2073-76.

23. Wang JG, Staessen JA, Fagard RH, Birkenhäger WH, Gong L, Liu L. Prognostic Significance of Serum Creatinine and Uric Acid in Older Chinese Patients With Isolated Systolic Hypertension. Hypertension: 2001; 37:1069.

J Bangladesh Soc Physiol. 2006 Dec;(1):19-26 